\title{
Variability in age and size at settlement of the tropical goatfish Upeneus tragula (Mullidae) in the northern Great Barrier Reef lagoon
}

\author{
Mark I. McCormick \\ Department of Marine Biology, James Cook University, Townsville, Qeensland 4811, Australia
}

\begin{abstract}
Age, size and body mass at settlement for the reef fish Upeneus tragula (Mullidae) were examined among 5 sampling stations across the northern Great Barrier Reef, over time periods ranging from days to 3 yr. Increments on the sagittal otoliths were validated as daily usiny tetracycline treatment. Fish were caught in their late pelagic stage, brought into the laboratory, and those that metamorphosed and settled to the bottom of the tank overnight were used in the study. Twenty-five samples of newly settled fish $(\mathrm{n}=6$ to 27 , mean $=14, \mathrm{~N}=345$ ) were compared. Larval durations ranged from 25 to $37 \mathrm{~d}$, and standard length varied similarly, ranging from 19 to $31 \mathrm{~mm}$ at settlement. Wet weight ranged from 0.09 to $0.61 \mathrm{~g}$. Significant differences in age, length and weight at settlement were found at all spatial and temporal scales. For instance, no consistent pattern in settlement characteristics was found among stations across the northern shelf, with one sample of settled fish of ten being significantly different in attributes from another sample from the same station a month or two later. Growth rate averaged over the whole larval period ranged from 0.55 to $1.0 \mathrm{~mm} \mathrm{~d}^{-1}$ Fish that settled larger tended to have lower growth rates than smaller fish. Patterns of increment widths throughout the larval phase were remarkably consistent among samples. However, the relationship between otolith length and fish length was found to vary significantly among samples collected within 2 mon from 4 locations. Results suggest the cautious use of back-calculation of larval sizes from otolith increment widths, and stress the underestimated importance of small-scale variation in larval growth dynamics. No evidence was found that $U$. tragula has the ability to delay settlement once developmental competence was attained.

KEY WORDS: Reef fish - Settlement - Age
\end{abstract}

\section{INTRODUCTION}

The size, age and developmental status of reef fish at settlement may play an important role in determining the subsequent dynamics of reef fish populations. Variation in the duration of the larval period may lead to decoupling of the spawning and recruitment cycles (Victor 1986a). On the other hand, variability in the age and body size of newly settling fish may influence their survival and role in the reef fish community. Despite the importance of settlement as the link between the larval and demersal life phases, it is only recently that attention has turned to behavioural and physiological events that occur at this transition, and the strong developmental link between events within the plankton and on the reef (e.g. Breitburg 1989, 1991, Champalbert et al. 1992a, b, McCormick 1993a).

Information is now available on the larval duration and size at settlement of over 300 species of tropical reef fish (e.g Brothers et al. 1983, Thresher \& Brothers 1985, 1989, Victor 1986b, Wellington \& Victor 1989). Levels of variability within a species range widely and appear to be related to the number of specimens collected (e.g. Thresher \& Brothers 1989). Unfortunately, sample sizes are typically small and collected from one site, and as a consequence little is known of the levels of variation. Still fewer studies have examined the relationship between age, size and body mass at settlement over time or across a number of spatial scales. Such information on natural levels of variability in 
growth over the larval period may suggest processes which determine mortality within the larval phase and the scales at which they operate.

The levels of variability in larval duration and size at settlement may be the result of a number of processes occurring throughout the larval stage. Chambers \& Leggett (1987), in a laboratory study of the flounder Pseudopleuronectes americanus, proposed that differences in settlement characteristics at metamorphosis were a product of differential larval growth rates. These reflect the interaction of the individual's developmental physiology with exogenous factors (food, temperature). Numerous studies now document the importance of food and temperature regimes in influencing larval growth and development rates (e.g. Houde 1974, 1989, Kiorboe et al. 1988), although there are still few demonstrations for reef fish.

A potentially important process influencing levels of variability, specific to reef-associated fish, is the capability of some species to delay metamorphosis in the absence of suitable settlement cues. Victor (1986a) and Cowen (1991) reconstructed larval growth rates from the patterns of otolith increment deposition and suggested that the 2 labrid species examined were capable of delaying settlement. These studies are complemented by the common field and laboratory observation of selectivity in the diel timing of settlement, and choice in the settlement microhabitat (e.g. Marliave 1977, Eckert 1985, Sweatman 1985, Roberts \& Ormond 1987). Together this evidence has resulted in the concept that fish larvae of demersal species reach a developmental threshold or level of 'competence' after which they can be induced to settle if given the appropriate cue. If cues are not forthcoming then settlement can be delayed. The magnitude and duration of this period of choice ('competence') has been inferred from changes in the deposition of microstructural increments in the fishes' otoliths.

The extent of a fish's ability to delay settlement is likely to depend on the species ecological requirements at the end of the larval stage. For instance, the settlement dynamics of a demersal reef fish with larvae that disperse widely and occur well away from suitable settlement habitat are likely to differ from pelagic fish whose larvae are already in their adult habitat. To date the only evidence for extensive delays come from the labrid family of reef fish, which are characterised by offshore larval distributions and long larval durations (e.g. Victor 1987, Cowen 1991, Wellington \& Victor 1992). Unfortunately, few studies have collected detailed information on larval durations of nonlabroid reef fishes. Detailed information on the variability in larval duration allows inferences to be made on the way the larvae interact with the pelagic environment and the mechanisms underlying these interactions.
The present paper evaluates the extent to which the exogenous control of developmental rates and potential for settlement delays govern larval duration and body size in a tropical goatfish species

Specifically, this study examines the levels of variability in the age, size and body mass at settlement for the freckled goatfish Upeneus tragula (Mullidae). Comparisons are made on a number of spatiotemporal scales: among sampling stations across the northern Great Barrier Reef (GBR) lagoon over 1 summer (1989/90); among samples collected over a 3 yr period (1989 to 1991 ) at 1 inter-reefal station and 1 station on the backreef of Lizard Island (1988 to 1990). The formation of daily otolith increments is validated and used to construct growth histories of individual fish. Increment widths in the otolith are compared among samples to suggest when in the larval phase the growth trajectories of the cohorts diverged.

\section{METHODS AND MATERIALS}

Species. Late-larval stage mullids are clupeiform in body shape and appearance. At approximately $7.5 \mathrm{~mm}$ standard length (SL) pelagic larvae join large schools comprised of a number of differing mullid species, each with a broad size distribution (McCormick \& Milicich in press). The largest individuals within these schools are competent to settle. Macroscopically, the metamorphosis that occurs at settlement involves marked changes in body pigmentation. The silver pelagic colouration changes to a mottled cream and fin and body stripes appear. The major changes in the shape of the fish at settlement, as occur in surgeonfish (Randall 1961) and serranids (Leis \& Rennis 1983), do not occur in mullids. However, recent studies have shown that at the microscopic level dramatic changes occur in the sensory system of the fish (McCormick 1993, McCormick \& Shand in press, Shand in press). These changes are rapid, occurring over a 6 to $12 \mathrm{~h}$ period, and involve both a loss of a layer of sensory cones from the dorsal retina, and expansion of the gustatory system.

Upeneus tragula settles in the shallow seagrass beds at the backreef of fringing reefs and also into the mixed seagrass and Halimeda $\mathrm{sp}$. beds that occur across the whole northern GBR lagoon. This suggests that the pelagic stages are always close to settlement substrata, and do not necessarily need to migrate into the vicinity of a coral reef to settle.

Mullids, unlike the commonly studied damselfishes, seldom settle to isolate patch reefs, or other manipulable substrata. Because of this it is not possible to obtain a sample of fish from the field that, with any certainty, have only just settled. Furthermore, it is not 
possible to collect a sample of fish that look as though they have recently settled and examine the otoliths for settlement marks since Upeneus tragula do not reliably lay down settlement marks in their otoliths (pers. obs.).

Sampling. Samples were collected in conjunction with a study that examined the spatio-temporal distribution patterns of mullids on the northern GBR (McCormick \& Milicich in press). Moored small plastic rafts $(1 \times 1 \mathrm{~m})$ were used to aggregate the late pelagic-stage mullids. Rafts were deployed for $4 \mathrm{~h}$ and the aggregated small fish were then collected with a plankton-mesh purse seine ( $14 \times 2 \mathrm{~m}, 0.5 \mathrm{~mm}$ mesh) using the methodology described by Kingsford \& Choat (1985). Once collected, a subsample of 50 to 1000 mullids was transferred to holding tanks of aerated seawater with a fine-mesh dip net, and brought back live to the Lizard Island Research station. Overnight some of the pelagic mullids changed pigmentation and settled to the bottom of the holding tanks. This study assumes that these fish were competent to settle when captured and would have settled that night if they had not been captured. This assumption is addressed in the discussion. These newly settled fish were killed by cold shock, weighed, measured and their otoliths removed.

Pelagic mullids were collected over 4 austral summers from December 1988 to December 1991. Three spatio-temporal comparisons of the age and size at settlement were made: (a) across the northern GBR (9 samples from November 1989 to January 1990); (b) at 1 inter-reefal station over 3 summers (16 summer samples from November 1989 to December 1991); (c) at 1 station on the edge of the Lizard Island fringing reef (4 samples from December 1988 to January 1990). Sample locations and dates are given in Table 1.

Five stations across the northern GBR lagoon were sampled once per month for 3 mo from November 1989 to January 1990. Station locations and their approximate depths were: $9 \mathrm{~km}$ NW of the Turtle Group $(13 \mathrm{~m}) ; 4 \mathrm{~km}$ south of Nymph Island $(17 \mathrm{~m}) ; 5 \mathrm{~km}$ north of Eagle Island $(23 \mathrm{~m}$ ); Lizard Island backreef (13 to $22 \mathrm{~m}$ ); midway between Lizard Island and Carter Reef (MLC, 30 to $40 \mathrm{~m}$ ) (Fig. 1). With the exception of Lizard Island station, 2 sites were established at each station, $500 \mathrm{~m}$ on each side of a stationary mother boat. At each site, 4 rafts were tethered, with $30 \mathrm{~m}$ lines linking the rafts to one another and to a single temporary mooring. Rafts were left for $4 \mathrm{~h}$ and then sampled with the purse seine. At the Lizard Island station, 4 to 6 rafts were moored individually along the edge of approximately $1.25 \mathrm{~km}$ of the backreef (for details see McCormick \& Milicich in press).
Table 1. Locations and dates of samples collected for the comparison of age and size at settlement of Upeneus tragula.

Number of newly settled fish within a sample is given

\begin{tabular}{|c|c|c|}
\hline Comparison & Date & $\mathrm{n}$ \\
\hline \multicolumn{3}{|l|}{ Cross-shelf } \\
\hline \multirow[t]{2}{*}{ Turtle } & 19 Nov 1989 & 27 \\
\hline & $16 \operatorname{Jan} 1990$ & 17 \\
\hline \multirow[t]{2}{*}{ Nymph } & 20 Nov 1989 & 20 \\
\hline & 30 Dec 1989 & 23 \\
\hline \multirow[t]{2}{*}{ Eagle } & 12 Nov 1989 & 6 \\
\hline & 28 Dec 1989 & 22 \\
\hline \multirow[t]{2}{*}{ Lizard Island } & 30 Nov 1989 & 23 \\
\hline & 4 Jan 1990 & 17 \\
\hline MLC & 21 Nov 1989 & 6 \\
\hline \multirow[t]{16}{*}{ Eagle Station } & 12 Nov 1989 & 6 \\
\hline & $28 \operatorname{Dec} 1989$ & 22 \\
\hline & $21 \mathrm{Jan} 1990$ & 20 \\
\hline & 10 Nov 1990 & 10 \\
\hline & 5 Dec 1990 & 11 \\
\hline & $14 \operatorname{Dec} 1990$ & 10 \\
\hline & $8 \mathrm{Jan} 1991$ & 10 \\
\hline & 10 Jan 1991 & 10 \\
\hline & 9 Nov 1991 & 12 \\
\hline & 13 Nov 1991 & 10 \\
\hline & 14 Nov 1991 & 11 \\
\hline & 18 Nov 1991 & 10 \\
\hline & 3 Dec 1991 & 11 \\
\hline & 8 Dec 1991 & 10 \\
\hline & 11 Dec 1991 & 10 \\
\hline & $16 \operatorname{Dec} 1991$ & 10 \\
\hline \multirow[t]{4}{*}{ Lızard Island Station } & 16 Dec 1988 & 9 \\
\hline & $23 \operatorname{Jan} 1989$ & 20 \\
\hline & 30 Nov 1989 & 23 \\
\hline & 4 Jan 1990 & 17 \\
\hline
\end{tabular}

Unfortunately, for some station by month combinations no newly settled fish were obtained, either because no fish were aggregated or none of the fish collected settled the night after capture. This resulted in 2 sampling dates per station (rather than the 3 planned) being used in the cross-shelf comparison of settlement size and age (except for the MLC station for

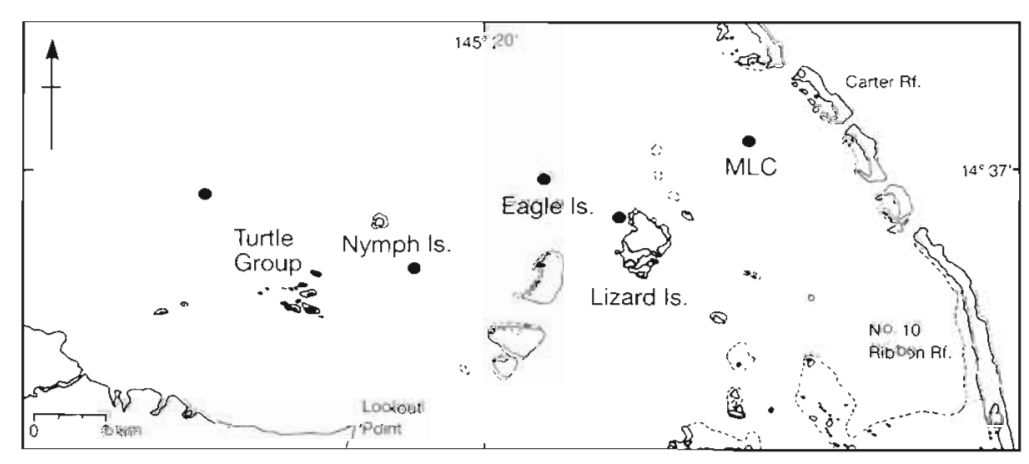

Fig. 1 Location of stations across the northern Great Barrier Reef at which aggregation rafts were used to sample pelagic mullids 
which newly settled fish were obtained on only one occasion). The restrictions of the sampling protocol (e.g. inadequate boat and live fish holding space) did not allow the separate maintenance of fish caught under individual rafts. Therefore, fish were lumped into a single overall sample from each sampling date. Samples of fish were collected at the Eagle station on 16 sampling dates, while samples from 4 dates were aged for the Lizard Island station.

One-way analyses of variance were used to test the null hypothesis of no significant difference in age, size or growth rates among the 9 samples from across the GBR lagoon, among the 16 samples from the Eagle station and among the 4 samples from the Lizard Island backreef. A posteriori Tukey's (HSD) tests examined the nature of any significant differences detected by ANOVA. For brevity a posteriori tests are not tabulated, but rather shown graphically or described in the text. Reference to a relationship being significant refers to statistical significance at the 0.05 level. A 2 -way nested ANOVA was used to examine the partitioning of the variability in age, size, weight and growth rate of Upeneus tragula between sampling months, among samples within a month and within samples. The 8 samples collected at the Eagle station during November and December 1991 were used in this analysis.

Ageing. Validation of daily increments: To validate the formation of daily otolith increments pelagic Upeneus tragula were immersed in a solution of tetracycline hydrochloride (250 $\mathrm{mg} \mathrm{l}^{-1}$ ) in seawater for $12 \mathrm{~h}$ in the dark. This placed a mark on the otolith which was fluorescent under ultraviolet light, and visible under transmitted light as a check. Fish were kept in tanks and fed Artemia sp. nauplii and finely chopped prawn for 23 days and nights, then re-immersed in tetracycline hydrochloride for $12 \mathrm{~h}$ and kept in tanks for a further approximately $20 \mathrm{~d}$. Otoliths were sectioned as detailed below and the number of increments between the 2 tetracycline-induced checks was compared to the number of days kept after immersion. The observed number of increments after the induced check mark did not differ from the expected number. with counts ranging from 21.7 to 23 increments (mean of 3 readings per otolith) (mean $22.7, \mathrm{SD}=0.35, \mathrm{n}=12$ ). This confirmed the daily formation of increments. To calculate age at settlement this study assumed that increment deposition started at hatching.

Otolith preparation: Transverse sections of the sagittal otoliths were used for ageing. Otoliths were measured along the primary axis and at the widest point perpendicular to that axis using a calibrated ocular micrometer. These were then heated for $5 \mathrm{~min}$ on a hot plate, mounted in a spurs-resin block and ground using wet carborundum paper (P600 and P1200) and lapping film ( 9 and $3 \mu \mathrm{m}$ ) to produce a transverse section through the nucleus. Otolith increments were read under immersion oil at $1000 \times$ magnification. Sections were read twice and if the counts differed by more than one increment were read a third time. Otoliths with a reading error $>10 \%$ were excluded from analysis ( 2 fish were excluded on this criterion). Mean increment counts were used in analyses.

To examine whether otolith increment spacing reflected the patterns seen in the rate of body growth over the whole larval period, the increment widths of 5 randomly chosen fish were measured for 3 samples. Increment widths were measured along a transect from the nucleus to the outer margin (Fig. 2) and measured with a calibrated video-analysis system linked to a compound microscope. Two of the 3 samples of fish chosen for examination were significantly different from one another in growth rate (Nymph 20 November 1989, Nymph 30 December 1989). The third sample was chosen at random to assess the generality of the increment width patterns. ANCOVAs were used to test for a difference in slopes of the linear portion of the increment curves ( 8 to $23 \mathrm{~d}$ ) among the 3 samples.

The relationship between size and otolith length for each of 2 samples from 4 cross-shelf sampling locations was examined with analysis of covariance (ANCOVA).

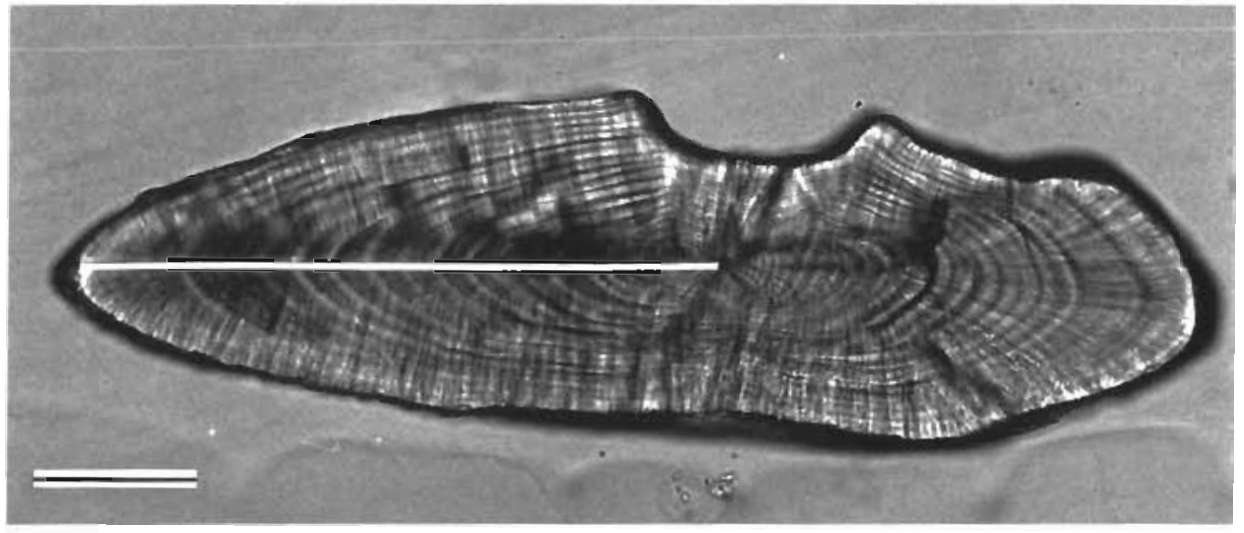

Fig. 2. Upeneus tragula. Transverse section of a sagitta showing the path along which increment widths were measured. Scale bar $=100 \mu \mathrm{m}$ 
This tested the null hypothesis that the population regressions were coincident. A Tukey's test compared the intercepts among the 8 samples to determine the nature of the significant difference found with ANCOVA (Zar 1984).

\section{RESULTS}

The age at settlement for Upeneus tragula from the northern GBR ranged from 25 to $37 \mathrm{~d}$, with a mode of $29 \mathrm{~d}$ and a mean of $31.1 \mathrm{~d}(\mathrm{SD}=2.5 \mathrm{~d})$. Overall, the distribution was normal with a broad peak between 29 and $33 \mathrm{~d}$ (Fig. 3). The overall SL at settlement showed a similar pattern, although slightly skewed toward the larger size classes of fish. Settlement size ranged from 19 to $31 \mathrm{~mm} \mathrm{SL}$, with a mode of 26 and a mean of $27.2 \mathrm{~mm}$ SL ( $\mathrm{SD}=1.9 \mathrm{~d}$ ). Overall there was slightly less variation in the size than in the age at settlement (CV 0.069 and 0.079 respectively). There was a poor relationship between length and age at settlement $\left(r^{2}=0.152, p<0.0001, n=345 ;\right.$ Fig. 3). An analysis of covariance (ANCOVA) found that the relationship between SL and age did not differ among samples (i.e. same slope), although intercepts differed. On the level of individual samples, relationships between SL and age were generally poor with regression coefficients ranging from 0.51 to 0.0001 (median 0.08 ) with 3 out of 25 regressions being significant at the 0.05 level

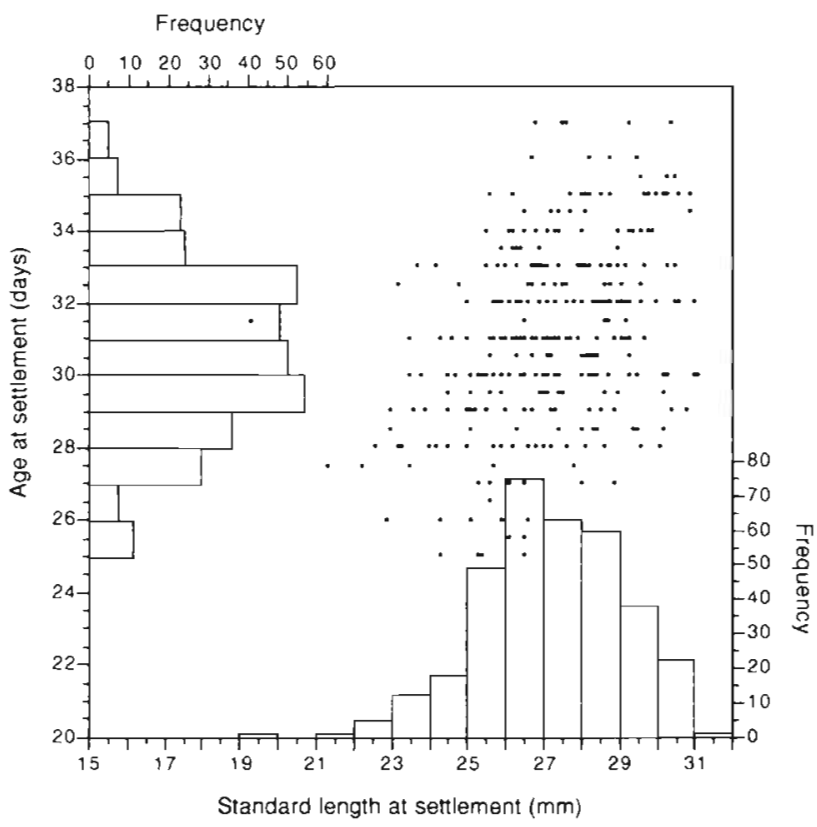

Fig. 3. Upeneus tragula. Relationship between size (mm SL) and age (d) for newly settled fish from the northern Great Barrier Reef. Equation: Age $=0.51(\mathrm{SL})+17.27, \mathrm{r}^{2}=0.152$, $p<0.0001$ Overall age and size frequency distributions are also given $(n=345)$

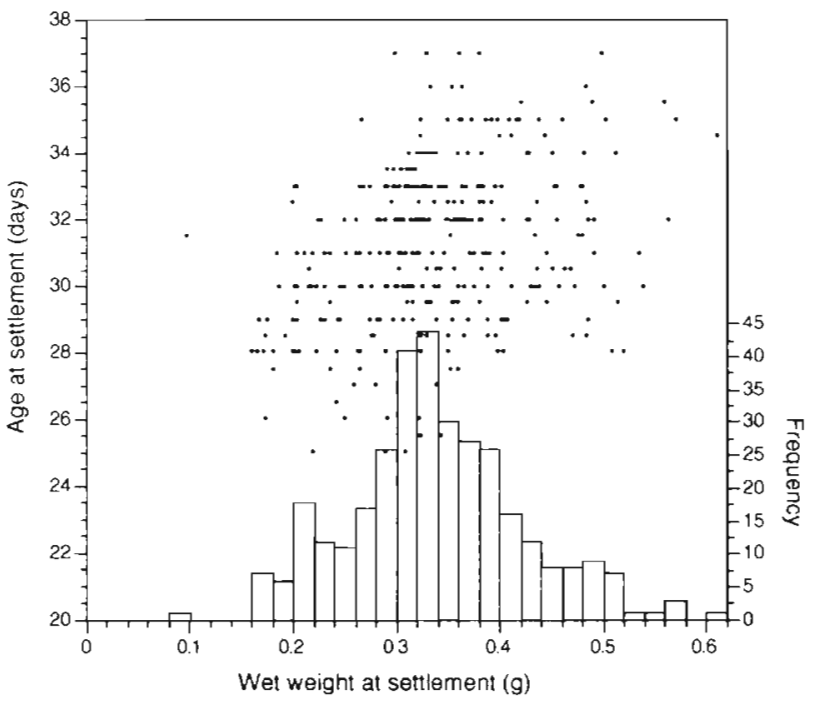

Fig. 4. Upeneus tragula. Relationship between wet weight (g) and age (d) of newly settled $U$. tragula from the northern Great Barrier Reef. Equation: Age $=9.51(w t)+2.8, r^{2}=0.11$, $p<0.0001$. A weight frequency distribution is given

Wet weight at settlement ranged from 0.09 to $0.61 \mathrm{~g}$, with a mean of $0.34 \mathrm{~g}(\mathrm{SD}=0.08 \mathrm{~g})$ and a mode of $0.33 \mathrm{~g}$ (Fig. 4). Not surprisingly, weight showed higher levels of variation compared to age or size ( $\mathrm{CV} 0.25)$. Weight was poorly related to age of the fish $\left(\mathrm{r}^{2}=0.11\right.$; Fig. 4). However, weight did show a strong relationship with standard length of the fish, although there was considerable variation around the exponential relationship $\left(w t=0.015 e^{01125 L} ; r^{2}=0.653, p<0.0001\right.$, $\mathrm{n}=338$ ).

When samples of newly settled Upeneus tragula collected over a range of spatial and temporal scales were compared, significant differences were found in the size, age and weight of the fish at all scales (Table 2. Fig. 5). Stations across the northern shelf showed no consistent pattern in size, weight or age at settlement, with 1 sample of settled fish at a station often being significantly different in attributes than another sample a month or 2 later (Fig 5). For example, the Nymph station fish in the December sample settled on average $4 \mathrm{~d}$ earlier, and were $13 \%$ smaller and $21 \%$ lighter, than fish in the November sample.

Similar levels of variation were found at the Eagle station for 16 samples, over 3 summers (Fig. 5). Here significant differences in age, size or weight were often found between consecutive samples from the same month, at times only separated by a single day (Table 2b). For instance, the mean larval duration of a sample of Upeneus tragula collected on 13 November 1991 was 33 d, significantly more than the 30 d larval duration of a sample collected the following day. Levels of variability in the 3 variables were formally compared 
Table 2. Upeneus tragula. Summary of analyses of variance comparing mean age (d) and size ( $\mathrm{mm} \mathrm{SL}$ ) at settlement and larval growth rate ( $\mathrm{mm} \mathrm{d}^{-1}$ ) among stations across the northern Great Barrier Reef between December 1988 and December 1991. (a) Comparison of mean ages of 9 samples from 5 stations across the northern shelf. (b) Comparison of 16 samples at the Eagle station. (c) Comparison of 4 samples from the Lizard Island station

\begin{tabular}{|llrrc|}
\hline Comparison & Source & df & MS & $p$ \\
\hline a. Cross sheli & & & & \\
Age & Sample & 8 & 47.083 & 0.0001 \\
& Error & 152 & 3.107 & \\
Size & Sample & 8 & 30.567 & 0.0001 \\
& Error & 152 & 2.789 & \\
Growth & Sample & 8 & 0.0132 & 0.0022 \\
& Error & 152 & 0.0041 & \\
b. Eagle station & & & & \\
Age & Sample & 15 & 19.557 & 0.0001 \\
& Error & 167 & 3.095 & \\
Size & Sample & 15 & 8.778 & 0.0001 \\
& Error & 167 & 1.554 & \\
Growth & Sample & 15 & 0.0190 & 0.0001 \\
& Error & 167 & 0.0030 & \\
c. Lizard Island station & & & & \\
Age & Sample & 3 & 61.176 & 0.0001 \\
Size & Error & 65 & 4.7129 & \\
& Sample & 3 & 35.481 & 0.0001 \\
Growth & Error & 65 & 3.418 & \\
& Sample & 3 & 0.0071 & 0.4112 \\
& Error & 65 & 0.0073 & \\
\hline
\end{tabular}

for the 8 samples collected from the Eagle station during November and December 1991 (4 each month) (Table 3). Age at settlement was not influenced by the month of sampling, with variation in settlement age being split between variation among samples within a month, and variation among fish within a sample (49.3 and $50.7 \%$ of the total variation respectively). On the other hand, the month of collection was an important determinant in the standard length and weight of fish at settlement, accounting for a much greater amount of the total variation than differences among samples within a month ( 19.7 vs $5.8 \%$ SL, 48.6 vs $8.9 \%$ wt). Both size and weight were greater in the December samples (Table 3). Upeneus tragula collected from the Lizard
Island backreef further emphasises the notion of significant variability occurring between samples at a single location (Table 2c, Fig. 5).

A rough approximation of the average larval growth rate to settlement was calculated by dividing the difference between the settlement and hatching size by the age at settlement. Leis \& Rennis (1983) have an illustration of a $2.6 \mathrm{~mm}$ mullid larvae that is well formed and has absorbed its yolk which is most likely Upeneus tragula. Hatching size is therefore estimated at $2 \mathrm{~mm}$ SL. Growth rates estimated in this way ranged from $0.55 \mathrm{~mm}$ to $1 \mathrm{~mm} \mathrm{~d}^{-1}$ ( $\mathrm{n}=345 \mathrm{fish}$ ). Larval growth rates differed among samples across the northern shelf (Table 2a, Fig. 6) and among 16 samples from the Eagle station (Table 2b, Fig. 6). Growth rates showed a significant increase over the sampling dates within 2 of the 3 summers for which data was collected. Growth rates did not differ among 4 samples from the Lizard station (Table 2c). A breakdown of the variation in growth rates among 8 samples collected over 2 mo at the Eagle station found that $21 \%$ of the variation in growth rate was explained by differences between sampling months (Table 3 ). A further $15 \%$ of the variation was explained by differences among samples within a month, while $64 \%$ of the variation was attributable to difference in growth rates among individual fish. Interestingly, fish that settled older tended to have lower growth rates averaged over the pelagic phase than fish that were younger at settlement (Fig. 7). An ANCOVA found that the magnitude of this negative relationship was a general trend shown by fish within all samples, although there were differences in the intercept values among samples (as suggested by Fig. 6).

Table 3. Upeneus tragula. Mean values by month and breakdown of total variation of age (d), size (mm SL), weight (g) at settlement, and estimated larval growth rates $\left(\mathrm{mm} \mathrm{d}^{-1}\right)$ for 8 samples collected in 2 mo (November and December 1991) at the Eagle station. Significance levels (p) given in brackets

\begin{tabular}{|lcccc|}
\hline & Age & Size & Weight & Growth \\
\hline Mean values by month & & & & \\
November 1991 & $32.2 \mathrm{~d}$ & $26.9 \mathrm{~mm} \mathrm{SL}$ & $0.33 \mathrm{~g}$ & $0.781 \mathrm{~mm} \mathrm{~d}^{-1}$ \\
December 1991 & $31.4 \mathrm{~d}$ & $28.1 \mathrm{~mm} \mathrm{SL}$ & $0.42 \mathrm{~g}$ & $0.835 \mathrm{~mm} \mathrm{~d}^{-1}$ \\
Source of variation & & & & \\
Month & $0 \%(0.591)$ & $19.7 \%(0.035)$ & $48.6 \%(0.008)$ & $20.7 \%(0.063)$ \\
Sample (month) & $49.3 \%(<0.0001)$ & $5.8 \%(0.086)$ & $8.9 \%(0.004)$ & $15.0 \%(0.006)$ \\
Residual & $50.7 \%$ & $74.5 \%$ & $42.5 \%$ & $64.3 \%$ \\
\hline
\end{tabular}


Fig. 5. Upeneus tragula. Growth characteristics of samples of newly settled fish ( $\mathrm{n}=6$ to 27 ). Three comparisons are made among: 5 stations across the northern Great Barrier Reef; 16 samples over 3 summers from 1 sampling station (Eagle); 4 samples over 2 summers from 1 station (Lizard). Notations: capitals for stations (T: Turtle, $\mathrm{N}$ : Nymph; E: Eagle; L: Lizard; MLC: midway between Lizard Island and Carter Reef); lower case letters for months ( $\mathrm{n}$ : November; d: December; j: January)
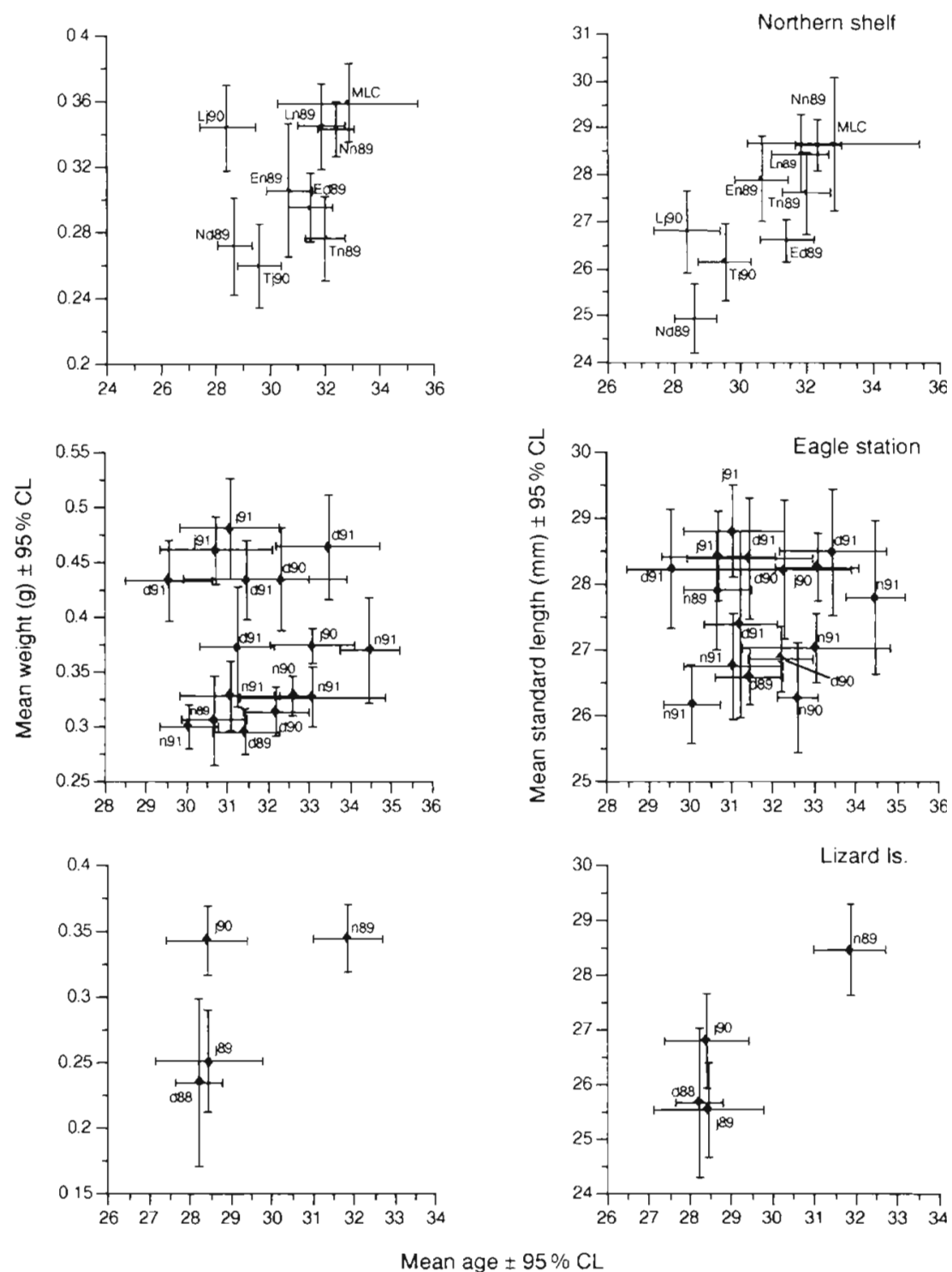

Increment widths on the sagittal otoliths were examined to determine whether they reflected the differences found in the average larval growth rates among samples. An examination of the increment widths of 2 samples from Nymph station 1 mo apart (November and December 1989) that significantly differed from one another in average larval growth rate, plus a third randomly selected from the other possible 23 samples (Eagle station, December 1989), illustrates 2 points (Fig. 8). Firstly, the pattern of increment spacings is remarkably consistent among all 3 samples up until increment 23 or 24 . After this point there is an abrupt end to the previously steady increase in otolith increment width. Secondly, ANCOVA found that the rate of increase in increment width was significantly higher, reaching an overall greater width, in the November sample than in fish caught in December at the Nymph station. (ANCOVA: df 1,176, p < 0.0001). Furthermore, the slope of the increment curve from the Eagle sample differed from the Nymph December sample, but not the November sample. This follows the trend of the average larval growth rates for the 3 samples $\left(0.85 \mathrm{~mm} \mathrm{~d}^{-1}\right.$, November Nymph; $0.79 \mathrm{~mm}$ $\mathrm{d}^{-1}$, December Eagle; $0.74 \mathrm{~mm} \mathrm{~d}^{-1}$, December Nymph) and the growth rates calculated specifically from the subset of 15 fish used in the comparison of increment spacings (shown in Fig. 8). It is interesting to note that although the growth rate differences among stations calculated in this approximate way are small, they are reflected in the rates of change of the increment widths. Examination of otoliths from field-settled Upeneus tragula show no other rapid narrowing of increments or consistent discontinuities that could be attributed to settlement. 


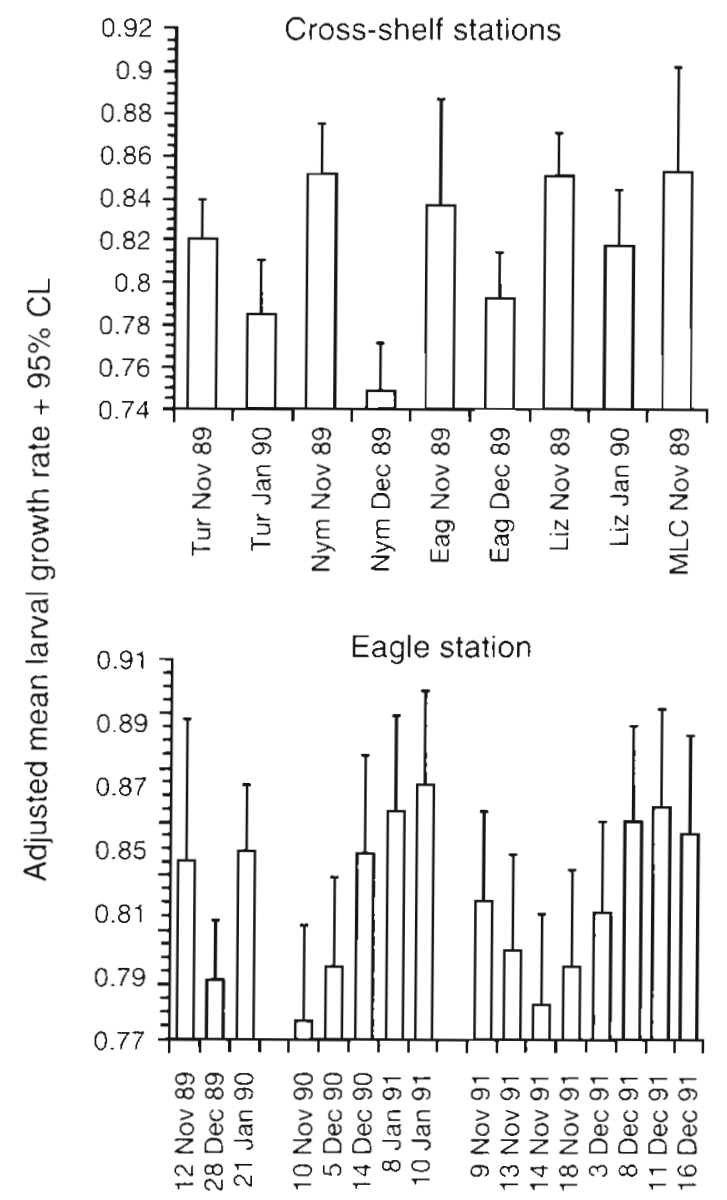

Fig. 6. Upeneus tragula. Comparison of the mean growth rates ( $\mathrm{mm} \mathrm{d}^{-1}$ ) averaged over the whole larval period among 9 samples collected across the northern Great Barrier Reef and among 16 samples from the Eagle station (Tur: Turtle; Nym: Nymph; Eag: Eagle; Liz: Lizard; MLC: midway between Lizard Island and Carter Reef). Growth rates are adjusted to account for variable age. Error bars are $95 \%$ confidence limits

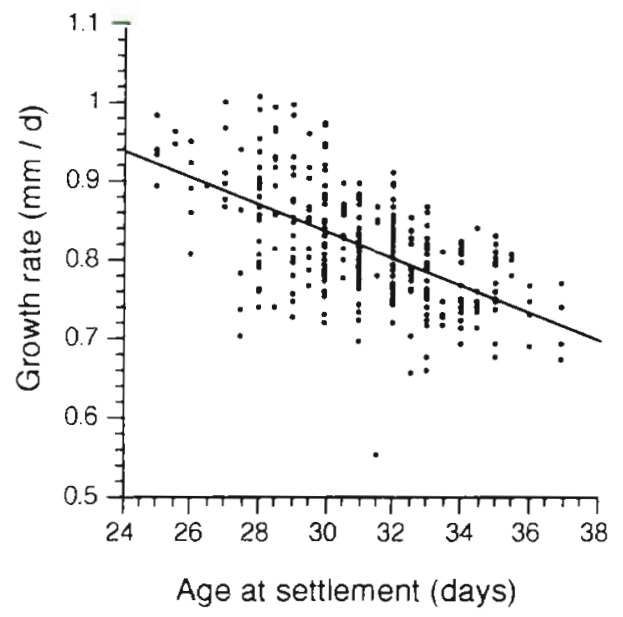

Fig. 7. Upeneus tragula. Relationship between average growth rate during the larval phase and age at settlement. Equation: $G R=-0.0167($ Age $)+1.33, r^{2}=0.34, p<0.0001, n=345$
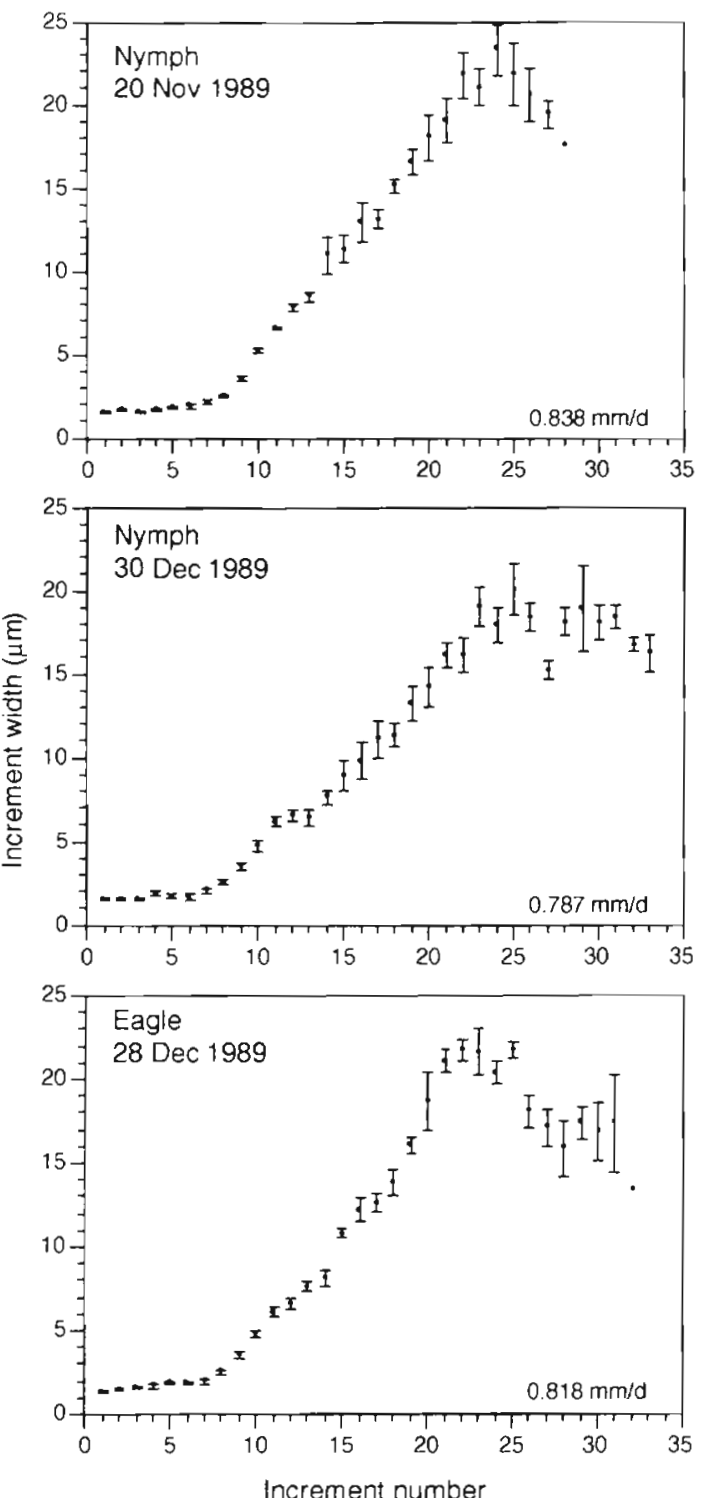

Fig. 8. Upeneus tragula. Increment widths from cross sections of sagitta from 3 samples of newly settled fish, 2 samples from the Nymph station and 1 from the Eagle station. Error bars are standard errors ( $\mathrm{n}=5 \mathrm{fish}$ ). Mean larval growth rate for the 5 fish used from each sample are given

The overall relationship between otolith length and SL was found to significantly differ among 8 samples collected from 4 stations across the northern GBR (Fig. 9, Table 4). No difference was found in the slopes of the regression lines among samples (Table 4a). This may be due to the low numbers of fish used to define each regression (17 to 27). However, the intercepts of the regressions did differ among samples, with significant differences occurring at all stations over time (Table $4 \mathrm{~b}$ ). 


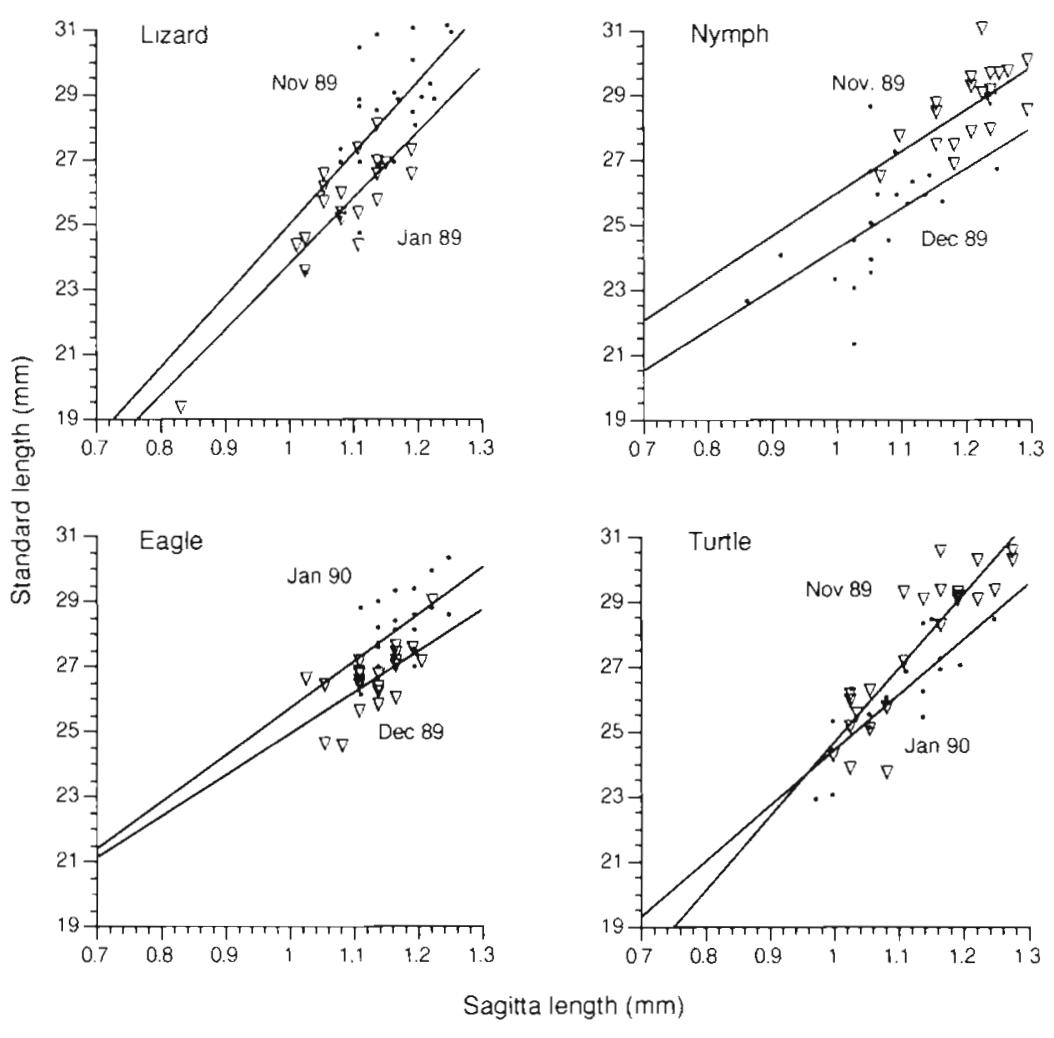

Fig. 9. Upeneus tragula. Relationship between standard length and sagittal otolith length for 8 samples of newly settled fish from 4 stations. ( $\nabla)$ Latter of the 2 sampling dates in each graph

Table 4. Upeneus tragula. Comparison of the relationship between sagittal otolith length (OL) and standard length (SL) among 8 samples of newly settled fish from 4 stations across the northern Great Barrier Reef. (A) ANCOVA summary table for tests of homogeneity of slopes and elevations. (B) Regression equations and coefficients calculated individually for each of 8 samples. All regressions are significant at $p<0.001$ Statistical groupings from pairwise comparisons of adjusted mean elevations are given

\begin{tabular}{|lcccc}
\hline $\begin{array}{l}\text { A. ANCOVA } \\
\text { Source }\end{array}$ & df & MS & $F$ & p \\
\hline Slope & 7,154 & 2.020 & 1.68 & 0.1177 \\
Elevation & 7,161 & 8.141 & 6.58 & 0.0001 \\
\hline
\end{tabular}

B. Regressing equations

\begin{tabular}{|c|c|c|c|c|}
\hline Grouping & Station, date & Equation & $\mathrm{n}$ & $r^{2}$ \\
\hline & Lizard, Nov 1989 & $\mathrm{SL}=21.99 \mathrm{OL}+3.00$ & 23 & 0.44 \\
\hline & Turtle, Nov 1989 & $\mathrm{SL}=22.86 \mathrm{OL}+1.77$ & 27 & 0.78 \\
\hline & Eagle, Jan 1990 & $\mathrm{SL}=14.64 \mathrm{OL}+11.08$ & 20 & 0.35 \\
\hline & Nymph, Nov 1989 & $\mathrm{SL}=12.90 \mathrm{OL}+13.04$ & 20 & 0.43 \\
\hline & Turtle, Jan 1990 & $\mathrm{SL}=17.14 \mathrm{OL}+7.26$ & 17 & 0.67 \\
\hline L & Eagle, Dec 1989 & $\mathrm{SL}=12.71 \mathrm{OL}+12.20$ & 22 & 0.45 \\
\hline & Lizard, Jan 1989 & $\mathrm{SL}=20.35 \mathrm{OL}+3.40$ & 20 & 0.75 \\
\hline L. & Nymph, Dec 1989 & $\mathrm{SL}=12.49 \mathrm{OL}+11.75$ & 21 & 0.34 \\
\hline
\end{tabular}

\section{DISCUSSION}

The growth characteristics of the freckled goatfish at settlement were found to vary significantly across sampling stations separated by kilometres, and at specific stations over time periods ranging from days to years. Similar levels of variability were found between days, years and among individuals within a single sample. The levels of variability identified in the age, size and mass of the settlers and their inter-relationship aid in identifying the factors that may potentially influence the settlement event. Furthermore it stresses the importance of the pelagic life history stage in shaping the demography of juvenile reef populations.

The levels of variability found in the size at settlement for Upeneus tragula, expressed as the coefficient of variation, span all other published accounts $(0.028$ to 0.082 , mean 0.051$)$ (e.g. Robertson et al. 1988: damselfish 0.062; Wellington \& Victor 1989: damselfish 0.04 to 0.07 ; Victor 1991: wrasse 0.055 to 0.063$)$. Similarly, levels of variation among samples in the age at settlement range widely (CV 0.02 to 0.1 , mean 0.06). Thresher \& Brothers (1989) found a strong relationship for Pomacentrids between the number of fish aged from a species and variability in its larval duration. However, for U. tragula the differences in the levels of variability shown cannot be attributed to sampling artefacts, since no such relationship exists among samples of different sizes $\left(F_{1,23}=\right.$ $0.227, \mathrm{p}=0.23$ ).

The sample sizes used in this study are similar to those typically used to quantify the larval durations and size at settlement for a species (6 to 27) (e.g. Wellington \& Victor 1989, mean $\mathrm{n}=7.2$ fish). The high and significant variability shown to occur among samples cautions against drawing biogeographic or regional conclusions on the range of larval durations from small sample sizes, collected at one time and location. Differences have been found before in the larval duration of reef fishes between areas or over time. Thresher et al. (1989) ex- 
amined the larval duration of Pomacentrus coelestis from 5 locations in the western Pacific. Despite a broad overlap, the mean age varied significantly among locations, ranging from 18.6 to $20.7 \mathrm{~d}$. Wellington \& Victor (1989) noted a significant difference between the larval duration of the damselfish Stegastes partitus in St. Croix (mean $=28.8 \mathrm{~d}, \mathrm{n}=14$ ) and Panama (mean $=$ $36.5 \mathrm{~d}, \mathrm{n}=206$ ). They also found that $S$. flavilatus in Panama had a much shorter larval life (mean $=27 \mathrm{~d}$, $\mathrm{n}=5$ ) than individuals in Ecuador (mean $=35.4 \mathrm{~d}, \mathrm{n}=$ 5). Differences found in the present study at the Eagle station in both size and age at settlement of Upeneus tragula between samples a day apart suggest that the geographic differences found in these and other studies (Victor 1986b. Thresher \& Brothers 1989, Thorrold \& Milicich 1990) may simply be the product of small-scale temporal variation at a single site. Information on the levels of variation at the lower spatial and temporal scales (e.g. among and within sites and months) may be required to validly interpret results at higher levels (e.g. among geographic locations).

Recently, Wellington \& Victor (1992) statistically examined the differences in the larval duration of the labrid Thalassoma lucasanum over 3 geographic locations in the eastern Pacific. At each location 2 samples of juveniles were collected, with individual samples at each location separated by a time frame of up to $7.5 \mathrm{yr}$. No differences were found in the larval durations between the 2 samples for any of the 3 locations. This result may have been due to the low replication within a location. However, the wide spread of the collections through time, and the consistency of the result among locations suggests that, for $T$. lucasanum at least. small-scale temporal and spatial variation within a location may contribute little to the overall variation in larval durations among geographic locations. The high variation in the larval durations among samples of Upeneus tragula found in the present study $(49 \%$ of the total variation), suggest this result is not universal and more attention is required to small-scale spatial and temporal variation. A better handle on levels of intraspecific variability in larval durations will enhance our ability to examine hypotheses concerning species integrity and genetic dispersal. Dispersal characteristics of a species will be linked to the individuals in the upper tail of the distribution of larval durations rather than the mean duration.

Getting realistic estimates of levels of variability in larval durations and size at settlement that are comparable to published accounts can be difficult given the range of methodologies used. Methodologies can be divided into the 6 categories listed in Table 5. All methods have inherent biases and problems that are likely to affect the mean and variance estimates. Many of these will be species dependent. A summary of some of the potential effects have been listed in Table 5 .

Table 5. Likely and potential biases of the mean and variance estimates of age and size at settlement of the main collection methods used ( $\times$ : unbiased estimate; $\uparrow$ : overestimate; $\downarrow$ : underestimate; ?: unknown effect)

\begin{tabular}{|c|c|c|c|c|c|}
\hline \multicolumn{2}{|l|}{ Method } & $\begin{array}{c}\text { Age } \\
\text { Mean Variance }\end{array}$ & \multicolumn{2}{|c|}{$\begin{array}{l}\text { Size } \\
\text { Mean Variance }\end{array}$} & Potential problems \\
\hline $\begin{array}{l}\text { 1. Back-calculation of } \\
\text { settlement from } \\
\text { juveniles }\end{array}$ & $\times ?$ & $\downarrow$ & ? & $?$ & $\begin{array}{l}\text { Subjectivity of identifying settlement checks, } \\
\text { inconsistent relationship of otolith size/fish size, } \\
\text { size or age dependent mortality prior to collection }\end{array}$ \\
\hline $\begin{array}{l}\text { 2. Reef collections from } \\
\text { patch reefs on day of } \\
\text { settlement }\end{array}$ & $\times ?$ & $\downarrow$ ? & $\times ?$ & $\downarrow ?$ & $\begin{array}{l}\text { Migration/mortality prior to collection may be size } \\
\text { or age dependent }\end{array}$ \\
\hline 3. Larval rearing ${ }^{c}$ & $?$ & $\uparrow$ & $\downarrow \uparrow$ & $\uparrow$ & $\begin{array}{l}\text { Tank artefacts, establishment of dominance } \\
\text { hierarchies }\end{array}$ \\
\hline 4. Pelagic sample ${ }^{d}$ & $\downarrow$ & $\uparrow$ & $\downarrow$ & $\uparrow$ & Includes fish that are not yet competent to settle. \\
\hline $\begin{array}{l}\text { 5. Pelagic sample settled } \\
\text { in laboratory" }\end{array}$ & $\times ?$ & $\times ?$ & $\times ?$ & $x$ ? & $\begin{array}{l}\text { If delay in settlement possible, may lead to } \\
\text { inducement of premature settlement in fish that } \\
\text { would not have settled in the field }\end{array}$ \\
\hline $\begin{array}{l}\text { 6. Smallest reef fish, } \\
\text { largest from plankton }\end{array}$ & $\begin{array}{ll}\text { Reef fish: } & \downarrow \\
\text { plankton: } & \uparrow\end{array}$ & $\downarrow$ & $\begin{array}{l}\downarrow \\
\uparrow\end{array}$ & $\downarrow$ & $\begin{array}{l}\text { Underrepresents large settlers from reef and small } \\
\text { settlers from the plankton }\end{array}$ \\
\hline \multicolumn{4}{|c|}{$\begin{array}{l}\text { ¿ Brothers \& McFarland (1981), Victor (1984), Thresher \& } \\
\text { Brothers (1985), Pitcher (1988), Hunt von Herbing \& } \\
\text { Hunte (1991), Wellington \& Victor (1992), Victor (in press) } \\
\text { brothers et al. (1983), Robertson et al. (1988) }\end{array}$} & \multicolumn{2}{|c|}{$\begin{array}{l}\text { 'Policansky (1983), Fukuhara (1986), Chambers \& Leggett (1987) } \\
{ }^{\mathrm{d}} \text { Thorrold \& Milicich (1990) } \\
\text { eThis study } \\
{ }^{\mathrm{f}} \text { Avise \& Shapiro (1986) Wellington \& Victor (1989) }\end{array}$} \\
\hline
\end{tabular}


The most commonly used technique is the backcalculation of settlement dates (and sometimes sizes) from a sample of the juvenile population (e.g. Thresher et al. 1986). Checks in the otolith, that are assumed to be due to the physiological and behavioural disruption associated with metamorphosis and settlement, are used as labels from which larval rings can be counted. Check identification is often a subjective process since otoliths are typically not as clear as those shown in publications, being marred by ghost rings and subdaily rings. To compound matters, the form of the settlement check differs greatly among species (e.g. Victor 1983, 1986a, b. Pitcher 1988, Fowler 1989, Lou 1993) and sometimes it is not until an experienced reader has examined a number of otoliths from the same species that its characteristics and approximate location become clear (D. C. Lou pers. comm., author's pers, obs.). Such problems may not bias the mean settlement age but may bias its associated variance estimate, by the exclusion or inclusion of unusually large or small presettlement counts. Size- or age-related mortality during the early days on the reef may further bias the sample. Pitcher's (1988) success in using back-calculation from otolith increments to reconstruct the known patterns of settlement of 2 pomacentrids at Lizard Island suggest that for at least some species these potential methodological problems are minimal. Unfortunately, inconsistent relationships between otolith size and fish size, as shown here and in other studies (e.g. Thorrold \& Milicich 1990), complicate the back-calculation of fish size at settlement or larval growth rates. The differences in the relationship found between months from the same location and between locations are of major concern and shed doubt on the conclusions of studies that have used a single pooled relationship to back-calculate fish sizes. In concert, these problems caution the use of back-calculation from settlement marks until the biases of the methodology (e.g. consistency of settlement mark formation) have been properly examined for the species of interest.

The methodology used in the present study, where a whole school or random subsample of pelagic stage fish are brought back to the laboratory and held overnight while some settle, is a useful alternative method of obtaining settlement ages and sizes. This method yields all fish that are potentially capable of settling to the reef. If fish were capable of delaying settlement then such a sample should also collect these fish with extended pelagic durations, except in the case where they have a different behaviour (possibly nonschooling) during the delay period. As with all the methods of collecting fish to estimate larval durations, experimental studies are required to examine the biases of the method. If further studies find that the larvae of some species are stimulated to settle earlier than they would under field conditions, then this method still yields an estimate of fish that are competent to settle. Under these circumstances, the larval durations may be slight underestimates and have higher associated variance estimates, that will lead to conservative statistical tests among samples. The increasingly widespread use of night lights to attract larval fish, and the wide array of taxa attracted (e.g. Doherty 1987), lend this technique to general use (e.g. Thorrold \& Milicich 1990).

The ecological consequences of variability in size when a fish comes back onto the reef are yet to be examined. In juvenile fish, and for larval fish in tanks, size has been found to correlate with social dominance and the acquisition of food (e.g. Coates 1980, Folkvord 1991). This extends to mate choice, retention and reproductive success (number of spawnings and fecundity) in adults (e.g. Hoffman 1985, DeMartini 1988). For newly settling fish, length-related characteristics may greatly affect which individuals are lost to predation during the early life on the reef. A potentially more important measure of fish quality may be its weight or bulk. Predictably this will vary more than length being exponentially related to length during the rapid growth phase of the larval fish (in this study overall CVs, 0.069 SL vs $0.25 \mathrm{wt}$ ). The current study found that the heaviest settling fish was 7 times the weight of the lightest. Body mass also has the potential to influence success (measured as survival or reproductive output) independent of length, since length only explained $65 \%$ of the variability in weight. After settlement these length-and weight-related pressures have the potential to enhance initially large differences in the larval growth rate $\left(0.55\right.$ to $\left.1 \mathrm{~mm} \mathrm{~d}^{-1}\right)$, and extend their influence well into the established reef population.

Few data exist on the processes which govern the levels of variability in larval growth rates and the age and size at settlement. The influence of density dependent factors on larval growth rates is unknown for reef fish. If growth rate is density dependent then a strong regulatory mechanism exists to stabilise the numbers of potential recruits (Houde 1989). Feeding history and water temperature during the pelagic stages have been experimentally shown to have marked effects on growth rates and body attributes at settlement. McCormick \& Molony (1992) found that they could induce major differences in growth attributes of Upeneus tragula (age, size, muscle development and body composition) with differing feeding regimes, despite the use of field caught larvae of unknown and variable parentage. McCormick (1992) found that $U$. tragula in $25^{\circ} \mathrm{C}$ water settled $2.7 \mathrm{~d}$ later than fish in $30^{\circ} \mathrm{C}$. However, size, muscle development and biochemical composition did not differ between the 2 treatments. The present information can be interpreted in the light of these studies. 
Growth rates averaged over the whole larval period tended to be higher in the samples collected from the Eagle station in December and January compared to those from November, for the summers $1990 / 1991$ and 1991/1992. These differences in growth rate and increment spacing may be due to a water temperature difference. Temperatures on the back-calculated spawning dates (using temperature data in McCormick 1992) differed between November and December samples by $2^{\circ} \mathrm{C}$. Differences of this magnitude have been found to be sufficient to influence the growth potential of reared fish larvae (Buckley 1982, Rana 1990). However, this trend in growth rate was not reflected by the cross-shelf sampling programme conducted during November 1989 to January 1990. Here fish in the November samples had slightly higher growth rates, and these were reflected in the otolith microstructure. Clearly, water temperature alone cannot explain the patterns of growth during November 1989 to January 1990. The influence of temperature and food availability are difficult to tease apart due to the effects of temperature on phytoplankton productivity. Samples from the Eagle station collected over 2 mo suggest that the processes of growth (in size) and differentiation (to metamorphosis) of the larvae are not necessarily influenced by the same factors. Experiments which examine the interaction of temperature and food availability on the growth parameters of fish larvae are required to elucidate the mechanisms driving the observed variability.

Patterns of increment deposition on the otoliths have been interpreted as records of development and growth (e.g. Victor 1986a, Kingsford \& Milicich 1987. Fowler 1989). In the present study, the shapes of the increment curves were very similar among samples, even though fish differed by as much as $8 \mathrm{~d}$ in their settlement ages. Day 8 , when the rate of increase in increment width abruptly increases, probably represents flexion. Interestingly, in all 3 samples the increase in increment width abruptly stops and begins to decrease at about Day 24. The suggestion that the somatic growth rate decreases after this point until settlement is supported by the negative relationship between growth rates averaged over the whole larval period and fish age at settlement. Such a trend could be interpreted as evidence for delayed settlement, with Day 24 representing the attainment of a 'competence' threshold.

I suggest that this is a misinterpretation of the increment pattern for 2 reasons. Firstly, the youngest fish to settle from all of the fish aged was $25 \mathrm{~d}$ old. If physiological 'competence' acted as a threshold then the settlement-age frequency distribution (Fig. 3) should be skewed towards the lower ages, with a considerable number of fish (or at least some) settling on Days 23 and 24. The age frequency curve is, however, normal with a median of $31 \mathrm{~d}$. The same argument against a competence threshold can be made when competence is defined as the attainment of a specific size, as determined by the smallest individual found to settle (e.g Victor 1986a, Wellington \& Victor 1992). Secondly, given the levels of variability in the biological and physical environment of the fish (e.g. temperature, food availability and quality etc.), and given the variable response of the fish to these conditions (growth rates, ages, weights etc.), then the consistency of the shapes of the increment width curves suggests an endogenously controlled process, largely divorced from exogenous influences. Higher variability after Day 24 suggests that development may be more greatly influenced by exogenous factors in the late pelagic stage. The apparent slowing of growth after Day 24 may be linked to limitations imposed by larval physiology (e.g. food processing efficiency) or morphological constraints (e.g. morphologically imposed maximum feeding rates, limitations of digestive tract morphology). Thus for Upeneus tragula at least, the shape of the otolith increment curve may be a blueprint for the development pattern of the species over the localities sampled. The scale to which it fits (i.e. absolute size of increment widths) may, however, be exogenously controlled. This does not preclude the possibility that $U$. tragula may be able to delay settlement, but simply means that presently there is no evidence for it.

The concept of 'competence' involves the development of the sensory system to a point where it can function competitively in the new reef environment, or it can undergo the rapid changes sometimes associated with metamorphosis (e.g. McCormick \& Shand in press). The development of the sensory systems, be they gustatory, visual or acoustic, have been found to be largely endogenously controlled, with the pattern of their development only being influenced by exogenous forces in periods of stress (e.g. starvation) (McCormick 1993). Thus the response of the endogenous controller to internal physiology will place the lower boundary on the timing of metamorphosis. Active choice of the settlement microhabitat has been found to occur in most reef fish (e.g. Eckert 1985). The important question is how large is the window of choice and what determines its upper bound. Is it restricted to a short period after the fish first enters the reef environment, as has been suggested from studies of flounder (e.g. Chambers \& Leggett 1987)? In October 1989 a strictly reef-associated fish (Parupeneus multifasciatus) with reef coloration and juvenile size (ca $65 \mathrm{~mm} \mathrm{SL}$ ) was observed feeding on plankton around a $1 \times 1 \mathrm{~m}$ fish aggregation raft, $5 \mathrm{~km}$ from Osprey Reef in the Coral Sea over $1000 \mathrm{~m}$ of water 
(B. A. Kerrigan, James Cook University, pers. comm.). This observation suggests that the upper temporal bound to settlement may be dependent on appropriate settlement cues for some species and not inextricably linked to metamorphosis.

The information presented here on a goatfish make an interesting comparison to studies on labrids and pomacentrids. Evidence for delays in settlement come from studies on labrids (Victor 1986a, Cowen 1991), many of which appear to occur well away from adult reefal habitats (e.g. Leis \& Miller 1976, Victor 1987). On the other hand, many pomacentrids appear to have shorter and less variable larval durations (e.g Thresher et al. 1989, Wellington \& Victor 1989, Thorrold \& Milicich 1990), with the larvae often occurring closer to potential settlement sites on the reefs (e.g. Leis \& Miller 1976). Cowen (1991) discussed in detail the relative importance of the precompetent and competent developmental stages in relation to the variability in larval durations among fish species and the fish's habitat requirements at settlement. He noted that one advantage of the capacity to delay metamorphosis is the flexibility to settle when a suitable settlement site is presented, or more importantly, when such a settlement site is not available, to continue to survive until such a site is located. The average distance of the fish at the end of the larval stage from suitable settlement sites (as approximated by Jackson \& Strathmann 1981 and Cowen 1991 by the length of the pre-competent stage) should be related to the capacity of the fish to delay settlement. In this regard, Upeneus tragula fits into the lower end of the spectrum of transport requirements. $U$. tragula forms joins pelagic schools of mullids at approximately $7.5 \mathrm{~mm} \mathrm{SL}$, about one-third of the way through its pelagic life history (McCormick \& Milicich in press). When it finally metamorphoses, it is capable of settling to the backreef seagrass beds, or inter-reefally into a mixed seagrass and sand habitat that extends across the northern Great Barrier Reef lagoon (author's pers. obs.). No long distance transport to the settlement habitat appears to be necessary, so the finding of no delay in settlement is perhaps unsurprising.

In summary, this study has shown that at times large and significant differences exist in the size, age and growth characteristics of a mullid species at settlement (as measured in the laboratory) over short time scales and within and among locations. These need to be taken into account if the link between the pelagic life history and demersal reef population is to be understood. The generality of this small-scale variability is yet to be assessed. At present the causes of this variability can only be speculated upon. Evidence suggests that for Upeneus tragula the pattern of larval development may be endogenously controlled while the magnitude of that growth is controlled by exogenous factors such as nutritional and temperature regimes. No evidence was found for the ability to delay settlement in this species. Further information is required on the mechanism underlying metamorphosis and settlement if we are to understand the limits to genetic dispersal in open populations, and the determinants of the quality of newly recruiting reef fish.

Acknowledgements. This research was funded by the Australian Museum through a Lizard Island Doctoral Research Fellowship and by an Australian Research Council minor research grant. Logistic support was provided by the Department of Marine Biology at James Cook University. Thanks to the many assistants who enthusiastically gave their time and humour to the project, in particular B. Kerrigan, B. Molony, J. McIlwain, V. Hall, L. Axe, S. Seddon and K. Tricklebank. Many helpful comments were made on earlier versions of this manuscript by $M$. Milicich, D. Booth and 3 anonymous reviewers. This paper is a contribution from the Lizard Island Research Station, a facility of the Australian Museum.

\section{LITERATURE CITED}

Avise, J. C., Sharpiro, D. Y (1986). Evaluating kinship of newly settled juveniles within social groups of the coral reef fish Anthias squamipinnis. Evolution 40: 1051-1059

Breitburg, D. L. (1989). Demersal schooling prior to settlement by larvae of the naked goby. Environ. Biol. Fish. 26: $97-103$

Breitburg, D. L. (1991). Settlement patterns and presettlement behaviour of the naked goby, Gobiosoma bosci, a temperate oyster reef fish. Mar. Biol. 109: 213-222

Brothers, E. B., McFarland, W. N. (1981). Correlations between otolith microstructure, growth, and life history transitions in newly recruited French grunts [Haemulon flavolineatum (Desmarest), Haemulidael. Rapp. P.-v. Réun. Cons. int. Explor. Mer 178: 369-374

Brothers, E. B., Williams, D. McB., Sale, P. F. (1983). Length of larval life in twelve families of fishes at 'One Tree Lagoon', Great Barrier Reef. Mar. Biol. 76: 319-324

Buckley, L. J. (1982). Effect of temperature on growth and biochemical composition of larval winter flounder Pseudopleuronectes americanus. Mar. Ecol. Prog. Ser. 8: 181-186

Chambers, R. C., Leggett, W. C. (1987). Size and age at metamorphosis in marine fishes: an analysis of laboratoryreared winter flounder (Pseudopleuronectes americanus) with a review of variation in other species. Can. J. Fish. Aquat. Sci. 44: 1936-1947

Champalbert, G., Macquart-Moulin, C., Patriti, G., Le DireachBoursier, L. (1992a). Light control of vertical movements of larvae and juvenile sole (Solea solea L.). Mar. Behav. Physiol. 19: 263-283

Champalbert, G., Macquart-Moulin, C., Patriti, G., Le DireachBoursier, L. (1992b). Ontogenetic fluctuations of geotaxis in larvae and juvenile sole (Solea solea L.). Mar. Behav. Physiol. 19: 251-261

Coates, D. (1980). Prey-size intake in humbug damselfish, Dascylus aruanus (Pisces, Pomacentridae) living within social groups. J. Anim. Ecology 49: 335-340

Cowen, R. K. (1991). Variation in the planktonic larval duration of the temperate wrasse Semicossyphus pulcher. Mar. Ecol. Prog. Ser. 69: 9-15 
DeMartini, E. E. (1988). Spawning success of the male plainfin midshipman. I. Influence of male body size and area of spawning site. J. exp. mar. Biol. Ecol. 121 177-192

Doherty, P. J. (1987). Light traps: selective but useful devices for quantifying the distributions and abundances of larval fishes. Bull. mar. Sci. 41:423-431

Eckert, G. J. (1985). Settlement of coral reef fishes to different natural substrata and at different depths. Proc. 5th Coral Reefs Congr. 5: 385-390

Folkvord, A. (1991). Growth, survival and cannibalism of cod juveniles (Gadus morhua): effects of feed type, starvation and fish size. Aquaculture 97: 41-59

Fowler, A. J. (1989). Description, interpretation and use of the micro-structure of otoliths from juvenile butterflyfishes (family: Chaetodontidae). Mar. Biol. 102: 167-181

Fukuhara, O. (1986). Morphological an functional development of Japanese flounder in early life stage. Bull. Jap. soc. scient. Fish 52: 81-91

Hoffman, S. G. (1985). Effects of size and sex on the social organization of reef-associated hogfishes, Bodianus spp. Environ. Biol. Fishes 14: 185-197

Houde, E. D. (1974). Effects of temperature and delayed feeding on growth and survival of larvae of three species of subtropical marine fishes. Mar. Biol. 26: 271-285

Houde, E. D. (1989). Subtleties and episodes in the early life of fishes. J. Fish. Biol. 35(Suppl.): 29-38

Hunt von Herbing, I., Hunte, W. (1991). Spawning and recruitment of the bluehead wrasse Thalassoma bifasciatum in Barbados, West Indies. Mar. Ecol. Prog. Ser. 72: 49-58

Jackson, G. A., Strathmann, R. R. (1981). Larval mortality from offshore mixing as a link between precompetent and competent period of development. Am. Nat. 118: 16-26

Kingsford, M. J., Choat, J. H. (1985). The fauna associated with drift algae captured with a plankton-mesh purse seine net. Limnol. Oceanogr. 30: 618-630

Kingsford, M. J., Milicich, M. J. (1987). Presettlement phase of Parika scaber (Pisces: Monocanthidae): a temperate reef fish. Mar. Ecol. Prog. Ser. 36: 65-79

Kiørboe, T., Munk, P., Richardson, K., Christensen, V., Paulsen, H. (1988). Plankton dynamics and larval herring growth, drift and survival in a frontal system. Mar. Ecol. Prog. Ser. 44: 205-219

Leis, J. M., Miller, J. M. (1976). Offshore distributional patterns of Hawaiian fish larvae. Mar. Biol. 36: 359-367

Leis, J M., Rennis, D. S. (1983). The larvae of Indo-Pacific coral reef fishes. University of Hawaii Press, Honolulu

Lou, D. C. (1993). Growth in juvenile Scarus rivulatus and Ctenochaetus binotatus: a comparison of families Scaridae and Acanthuridae. J. Fish. Biol. 42: 15-23

Marliave, J. B. (1977). Substratum preferences of settling larvae of marine fishes reared in the laboratory. J. exp. mar. Biol. Ecol. 27: 47-60

McCormick, M. 1. (1992). The influence of pelagic lite history on the quality of tropical goatfish (family Mullidae) at settlement. Ph.D. dissertation, James Cook University, Townsville

McCormick, M. 1. (1993). Development and change at settlement in the barbel structure of the reef fish, Upeneus tragula (Family: Mullidae). Environ. Biol. Fish. 37: $269-282$

McCormick, M. I., Milıcich, M. J. (in press). Late pelagicstage goatfishes: distrubution patterns and inferences on schooling behaviour. J. exp. mar. Biol. Ecol.

McCormick, M. I., Molony, B. W. (1992). Effects of feeding history on the growth characteristics of a reef fish at settlement. Mar. Biol. 114: 165-173

McCormick, M. I, Shand, J. (in press). Metamorphosis of the visual and barbel sensory systems at settlement in the reef fish Upeneus tragula (Family Mullidae). Proc. 7th. Int. Coral Reefs Symp.

Pitcher, C. R. (1988) Validation of a technique for reconstructing daily patterns in the recruitment of coral reef damselfish. Coral Reefs 7: 105-111

Policansky, D. (1983). Size, age and demography of metamorphosis and sexual maturation in fishes. Am. Zool. 23 $57-63$

Rana, K. J. (1990). Influence of incubation temperature on Oreochromis niloticus (L.) eggs and fry II. Survival, growth and feeding of fry developing soley on their yolk reserves. Aquaculture 87: 183-195

Randall, J. E. (1961). A contribution to the biology of the convict surgeonfish of the Hawailan islands, Acanthurus sandvicensis. Pacif. Sci. 15: 215-272

Roberts, C. M., Ormond, R. F. G. (1987). Habitat complexity and coral reef fish diversity and abundance on Red Sea fringing reefs. Mar. Ecol. Prog. Ser. 41: 1-8

Robertson, D. R., Green, D. D., Victor, B. C. (1988). Temporal coupling of production and recruitment of larvae of a Caribbean reef fish. Ecology 69: 370-381

Shand, $J$. (in press). Changes in retinal structure during development and settlement of the goatfish Upeneus tragula. Brain Behav. Evol.

Sweatman, H. (1985). The timing of settlement by larval Dascyllus aruanus: some consequences for larval habitat selection. Proc. 5th Int Coral Reef Congr. 5: 367-371

Thorrold, S. R., Milicich, M. J. (1990). Comparison of larval duration and pre-and post-settlement growth in two species of damselfish. Chromis atripectoralis and Pomacentrus coelestis (Pisces: Pomacentridae), from the Great Barrier Reef. Mar. Biol. 105: 375-384

Thresher, R. E., Brothers, E. B. (1985). Reproductive ecology and biogeography of Indo-west Pacific anglefishes (Pisces: Pomacanthidae). Evolution 39: 878-887

Thresher, R. E., Brothers, E. B. (1989). Evidence of intra- and inter-oceanic regional differences in the early life history of reef-associated fishes. Mar. Ecol. Prog. Ser. 57: 187-205

Thresher, R. E., Colin, P. L., Bell, L. (1989). Planktonic duration, distribution and population structure of western and central Pacific damselfishes (Pomacentridae). Copeia 1989: $420-434$

Thresher, R. E., Sainsbury, K. J., Gunn, J. S., Whitelaw, A. W. (1986). Life history strategies and recent changes in population structure in the lizardfish genus, Saurida, on the Australian Northwest Shelf. Copeia 1986: 876-885

Victor, B.C. (1983). Settlement and larval metamorphosis produce distinct marks on the otoliths of the slippery dick, Halichoeres bivittatus. In: Reaka, M. L. (ed.) The ecology of deep and shallow coral reefs. NOAA Symp. Ser. Undersea Res. 1. 47-51

Victor, B. (1984). Coral reef fish larvae: patch size estimation and mixing in the plankton. Limnol. Oceanogr 29: $1116-1119$

Victor, B. C. (1986a). Delayed metamorphosis with reduced larval growth in a coral reef fish (Thalassoma bifasciatum). Can. J. Fish. Aquat. Sci. 43: 1208-1213

Victor, B. C. (1986b). Duration of the planktonic larval stage of one hundred species of Pacific and Atlantic wrasse (family Labridae). Mar. Biol. 90:317-326

Victor, B. C. (1987). Growth, dispersal, and identification of planktonic and pomacentrid reef-fish larvae in the eastern Pacific Ocean. Mar. Biol. 95: 145-152

Victor, B. C. (1991). Settlement strategies and biogeography of reef fishes. In: Sale. P. F. (ed.). The ecology of tishes on coral reefs Academic Press, San Diego, p. 231-260 
Victor, B. C. (in press). Comparative early life-history and settlement patterns in a pair of congeneric coral-reef fishes. Mar. Biol.

Wellington, G. M., Victor, B. C. (1989). Planktonic larval duration of one hundred species of Pacific and Atlantic damselfishes (Pomacentridae). Mar. Biol. 101: 557-567

This article was presented by D. M. Alongi, Townsville, Queensland, Australia
Wellington, G. M., Victor, B. C. (1992). Regional differences in duration of the planktonic larval stage of reef fishes in the eastern Pacific Ocean. Mar. Biol. 113: 491-498

Zar, J. H. (1984). Biostatistical analysis. Prentice-Hall, Englewood Cliffs

Manuscript first received: December 23, 1992

Revised version accepted: August 24, 1993 